\title{
ВЛИЯНИЕ ТИПА ПОЧВ НА УРОЖАЙНОСТЬ ЗЕРНОВЫХ КУЛЬТУР В НОВОСИБИРСКОЙ ОБЛАСТИ
}

\section{Анастасия Александровна Рубцова}

Сибирский государственный университет геосистем и технологий, 630108, Россия, г. Новосибирск, ул. Плахотного, 10, обучающийся, тел. (913)894-72-75, e-mail: rubcova-anastasiamail.ru@mail.ru

\section{Юрий Степанович Ларионов}

Сибирский государственный университет геосистем и технологий, 630108, Россия, г. Новосибирск, ул. Плахотного, 10, доктор сельскохозяйственных наук, профессор кафедры экологии и природопользования, тел. (953)859-85-80, e-mail: larionov42@mail.ru

В статье рассмотрены и приведены результаты математическо-статистического анализа урожайности и типов почв, на которых возделываются зерновые культуры; использованных доз минеральных и органических удобрений; качества семян. Исследования показали необходимость совершенствования технологии возделывания зерновых культур в масштабах области и показателей мониторинга плодородия почв.

В качестве исходного материалы были взяты статистические данные за 2017 год по урожайности в разрезе районов по Новосибирской области.

Основной метод: корреляционный анализ и компьютерная программа Microsoft Excel.

Ключевые слова: почва, плодородие, урожайность, корреляционный анализ, коэффициент корреляции, органические и минеральные удобрения

\section{THE IMPACT OF SOIL TYPE ON CROP YIELDS IN THE NOVOSIBIRSK REGION}

\section{Anastasia A. Rubtsova}

Siberian State University of Geosystems and Technologies, 10, Plakhotnogo St., Novosibirsk, 630108, Russia, Student, phone: (913)894-72-75, e-mail: rubcova-anastasiamail.ru@mail.ru

\section{Yuri S. Larionov}

Siberian State University of Geosystems and Technologies, 10, Plakhotnogo St., Novosibirsk, 630108, Russia, D. Sc., Department of Ecology and Environmental Management, phone: (953)859-85-80, e-mail: larionov42@mail.ru

The article examines and presents the results of mathematical and statistical analysis of yields and soil types on which crops are cultivated; Doses of mineral and organic fertilizers; seed quality. Studies have shown the need to improve the technology of crop cultivation on a regional scale and indicators of soil fertility monitoring.

As the source material, statistics for 2017 on yields in the novosibirsk region were taken.

The main method is correlation analysis and Microsoft Excel computer program.

Keywords: soil, fertility, yield, correlation analysis, correlation ratio, organic and mineral fertilizers, research, result

В настоящее время урожайность зерновых культур по Новосибирской области остаётся на низком уровне (от 10 до 20 центнеров на га.). Чтобы повысить урожайность зерновых культур, необходимо, в первую очередь, использовать 
высокоурожайные семена современные технологии возделывания и повысить агротехнику (система приёмов возделывания культурных растений) за счёт внесения минеральных и органических удобрений, борьбы с сорной растительностью, чёткого соблюдения севооборота [1-5]. В связи с этим, актуальным является исследование эффективности использования минеральных и органических удобрений в масштабах Новосибирской области $[6,7]$.

Установленные коэффициенты корреляции (табл. 1) между урожайностью посевов зерновых культур и типами почв по плодородию показывают, что степень влияния плодородия на урожайность у большинства почв не высокая (незначительная). Это связанно с тем, что урожайность, являясь интегральным показателем может быть связанна не только с изучаемым показателем, но и рядом других.

Таблий 1

Коэффициент корреляции урожайности зерновых культур с типом почв

\begin{tabular}{|l|l|c|c|}
\hline \multicolumn{2}{|l|}{$\begin{array}{l}\text { Коррелируемые признаки: уро- } \\
\text { жайность } \\
\text { тип почв }\end{array}$} & $\begin{array}{l}\text { Коэффициент } \\
\text { парной корреля- } \\
\text { ции }\end{array}$ & Характер связи \\
\hline \multirow{3}{*}{$\begin{array}{l}\text { Урожай- } \\
\text { ность }\end{array}$} & - черноземы, \%; & 0,175 & $\begin{array}{c}\text { практически отсут- } \\
\text { ствует }\end{array}$ \\
\cline { 2 - 4 } & $\begin{array}{l}\text { - серые оподзолен- } \\
\text { ные, \%; }\end{array}$ & 0,341 & слабая \\
\cline { 2 - 4 } & - болотные, \%; & $-0,265$ & отрицательная \\
\cline { 2 - 4 } & - луговые, \%; & $-0,255$ & отрицательная \\
\cline { 2 - 4 } & - солонцы, \%. & $-0,341$ & отрицательная \\
\hline
\end{tabular}

Каким способом повысить урожайность, если тип почв имеет слабое влияние? Проведем исследование корреляционной зависимости урожайности зерновых культур в масштабах области (по районам) при внесении минеральных и органических удобрений (табл. 2).

Таблица 2

Коэффициент корреляции между урожайностью зерновых культур и внесением удобрений

\begin{tabular}{|l|l|}
\hline Показатели & Коэффициент корреляции \\
\hline $\begin{array}{l}\text { Урожайность и минеральные удобре- } \\
\text { ния }\end{array}$ & 0,72 \\
\hline $\begin{array}{l}\text { Урожайность и органические удобре- } \\
\text { ния }\end{array}$ & $-0,07$ \\
\hline Урожайность и азотные удобрения & 0,75 \\
\hline
\end{tabular}


Исследования показывают, что использование минеральных удобрений в масштабах области оказывает положительное влияние на урожайность зерновых культур. Об этом свидетельствует коэффициент корреляции между урожайностью и дозой внесения как азотных, так и в целом минеральных удобрений (NPK) от 0,72 до 0,75.

Органические удобрения не оказывают заметного влияния на урожайность, так как коэффициент корреляции отрицательный. Отсутствие связи связано с минимальным количеством внесения самих удобрений (от 0,19 до 1,67 центнеров на га). В то время, как органика должна вноситься в тоннах [8].

Исследование зависимости качества семян, кондиционных по показателю ГОСТ не оказывают влияния на урожайность в связи с тем, что показатели посевных свойств (всхожесть, влажность, чистота) сами слабо коррелируют с урожайностью (коэффициент корреляции $-0,03$ ). Оценка урожайности семян ГОСТом не предусматривается.

Необходимо также отметить, что современное состояние растениеводства связано не только со снижением плодородия почв, но и их качественным составом (вероятно, поэтому многие коэффициенты корреляции с используемыми агрохимическими показателями низкие). Одновременно можно сделать вывод о необходимости совершенствования оценки качества почв (мониторинг) по плодородию. А потому сельскохозяйственное производство нуждается в разработке и внедрении новых технологий возделывания зерновых культур [9-12]. По мнению многих специалистов земледелие и растениеводство должно стать не только более продуктивным, но и в большей степени биологическим, с минимизацией вносимых в почвы доз химических препаратов, использования химических средств защиты растений, для обеспечения производства экологически чистой продукции и лучшей сохранности агроценозов [13].

\section{БИБЛИОГРАФИЧЕСКИЙ СПИСОК}

1. Ларионов Ю.С. Управление адаптивностью сорта / Ю.С. Ларионов, Л.М. Ларионова, Е.П. Новокрещинов - Челябинск: Челябинский ГАУ, 2004. - 301 с.

2. Березин Л.В., Кленов Б.М. В.В. Леонова. Экология и биология почв. ФГОУ ВПО ОмГАУ, Омск. - 122с.

3. Курдюмов Н.И. Мастерство плодородия /Н.И. Курдюмов. - Ростов на Дону: Изд. Дом «Владис», 2007. - 512c.

4. Овсянников Ю.А. Теоретические основы эколого-биосферного земледелия./Ю.А. Овсянников, - Екатеринбург, изд. Уральского ГУ, 2000. - 263с.

5. Конев А.А. Система биологизации земледелия. Новосибиский ГАУ, Новосибирск, 2004. $-51 \mathrm{c}$.

6. КирюшинВ.И. Теория адаптивно-ландшафтного земледелия и проектирование агроландшафтов. /В. И. Кирюшин, М. «КолосС» 2011. - 443с.

7. Каштанов А. Н. Основы ландшафтно-экологического земледелия. / А. Н. Каштанов, Ф. Н. Лисецкий, Г.И. Швебс/ - М.: Колос, 1994. - 383с.

8. Яшутин Н.В., Дробышев А.П., Хоменко А.И. Биоземледелие (научные основы, инновационные технологии и машины)./ Н.В. Яшутин, А.П. Дробышев, А.И. Хоменко - Барнаул, изд. АГАУ, 2008. $191 \mathrm{c}$. 
9. Жарников В.Б., Ларионов Ю.С. Мониторинг плодородия земель сельскохозяйственного назначения как механизм их рационального использования. Вестник СГУГиТ. - 2017. Том 22, №1. - C. 203-210.

10. Штерншис М.В. Биологическая защита растений./М.В. Штерншис. М.: «КолосС» 2004.- 264c.

11. Ларионов Ю.С. Закон плодородия почв. Теоретические и методологические основы. Монография. СГУГИТ, Новосибирск. 2020. - 275 с.

12. Лящев А,А. Почвенная биота и плодородие почвы в условиях юга Западной Сибири. - Тюмень: ТюмГСХА, 2004. - 252c.

13. Ларионов Ю.С. Пути повышения продуктивности и стабильности функционирования агроэкосистем /Ю.С. Ларионов, Н.А. Ярославцев, А.А. Косов, О.А. Ларионова - Сб. материал. II межд. науч.-практ. конф. «Эколого-экономическая эффективность природопользов. На современ. этапе развития Западно-Сибирского региона» Омск, ОмГПУ, 2008 - С.100-104.

(C) А. А. Рубиова, Ю. С. Ларионов, 2021 